

Jurmal

Editor-Reviewer Article :Dsk. Pt. Mas Ari Candrawati \&L Eny Puspani

\title{
PERBANDINGAN DUA SISTEM KEMITRAAN AYAM BROILER PADA KANDANG CLOSED HOUSE
}

\author{
Adnyana, I P.G.G., I G. Mahardika, I W. Sukanata \\ PS. Sarjana Peternakan, Fakultas Peternakan, Universitas Udayana, Denpasar, Bali \\ Email: gedegiriadnyana@ student.unud.ac.id, Telepon: +6281949721286
}

\begin{abstract}
ABSTRAK
Penelitian bertujuan untuk mengetahui perbandingan dua sistem kemitraan ayam broiler pada kandang closed house yang dilaksanakan selama 2 bulan dari bulan Oktober sampai dengan bulan November 2019. Variabel yang digunakan dalam penelitian ini meliputi pertambahan bobot badan, konsumsi pakan, deplesi, Feed convertion ratio (FCR), Indeks performa (IP), kontrak sistem A dan sistem B. Penelitian menggunakan data selama 7 periode pemeliharaan. Data penelitian dianalisis secara deskriptif pada aspek pola kemitraan dari sitem A dan B serta performa produksi. Hasil penelitian ini menunjukkan sistem A dan B sama-sama menerapkan kemitraan inti plasma dan terdapat perbedaan pada pemberian bonus, sistem A memberikan bonus FCR, deplesi dan IP sedangkan sistem B memberikan bonus FCR dan harga pasar. Hasil penelitian ini juga menunjukan bobot rata-rata ayam pada umur 29 hari sebesar $1,317 \mathrm{~kg} / \mathrm{ekor}$, rataan pertambahan bobot badan 1,278 kg/ekor, rataan konsumsi rasum 1,920 kg/ekor, rataan nilai FCR 1,488, rataan tingkat deplesi 2,276 dan rataan indeks performa ayam broiler sebesar 297,490. Berdasarkan hasil penelitian dapat disimpulkan bahwa sistem A dan sistem B memiliki perbedaan pada sistem pembagian bonus serta rata-rata performa produksi dari 7 periode pemeliharaan masih di bawah standar sistem A dan sistem B.
\end{abstract}

Kata kunci: sistem kemitraan, ayam broiler, closed house

\section{THE COMPARISON OF TWO BROILER CHICKEN PARTNERSHIP SYSTEMS IN CLOSED HOUSE CAGE}

\begin{abstract}
The research aims to determine the comparison of two broiler chicken partnership systems in a closed house cage that was conducted for 2 months from October to November 2019. Variables used in this study include weight gain, feed consumption, depletion, Feed convertion ratio (FCR), Performance index (IP), contract system A and system B. The study uses data for 7 maintenance periods. The research data were analyzed descriptively on aspects of the partnership pattern of the A and B systems and production performance. The results of this study indicate that systems A and B both implement plasma core partnerships and there are differences in bonuses, system A gives FCR, depletion and IP bonuses while system B provides FCR bonuses and market prices. The results of this study also showed the average weight of chickens at the age of 29 days was $1.317 \mathrm{~kg} / \mathrm{head}$, the average weight gain of 1.278
\end{abstract}


$\mathrm{kg} / \mathrm{head}$, average consumption of $1,920 \mathrm{~kg} / \mathrm{head}$, average FCR value of 1,488, average depletion rate of 2,276 and average performance index broiler chickens at 297,490. Based on the results of the study it can be concluded that system A and system B have differences in the bonus distribution system and the average production performance of the 7 maintenance periods is still below the standard system A and system B.

Keywords: partnership system, broiler chickens, closed house

\section{PENDAHULUAN}

Sektor peternakan di Indonesia sangat diperlukan untuk menunjang kebutuhan protein hewani di masyarakat terutama daging. Permintaan daging ayam di Indonesia sangat tinggi, hal tersebut dipengaruhi oleh pertumbuhan penduduk yang semakin meningkat. Menurut data Badan Pusat Statistik (2019) pertumbuhan penduduk Indonesia dari tahun 2015-2019 sebanyak 1,19\%. Hal tersebut sejalan dengan jumlah konsumsi daging ayam pada tahun 2015 mencapai 4,944 kg per kapita/tahun dan meningkat pada tahun 2018 menjadi 5,808 kg per kapita/tahun (BPS, 2018). Tingginya permintaan daging ayam harus didukung dengan produksi yang tinggi guna menunjang kemandirian pangan.

Penerapan kandang dengan sistem closed house merupakan salah satu cara untuk meningkatkan produksi ayam broiler. Kandang closed house adalah kandang dengan sistem tertutup sehingga suhu, ventilasi dan kelembaban kandang dapat diatur sedemikian rupa. Hal tersebut sejalan dengan pendapat Wulansari et al., (2018) yang menyatakan bahwa kandang closed house dapat memperkecil angka mortalitas dan mempercepat pertumbuhan sehingga dapat mempengaruhi tingkat pendapatan peternak. Prinsip dasar kandang closed house adalah mencegah pengaruh lingkungan sekitar seperti suhu dan intensitas cahaya matahari yang berlebih masuk ke dalam kandang. Selain itu, sistem kandang closed house juga dapat meminimalkan penyebaran penyakit dari luar ke dalam kandang (Primaditya et al., 2015).

Terdapat dua sistem produksi ayam broiler di Indonesia yaitu sistem mandiri dan sistem kemitraan. Sistem mandiri merupakan sistem usaha peternakan ayam broiler dengan modal sepenuhnya ditanggung peternak. Sedangkan kemitraan merupakan strategi bisnis yang dilakukan oleh dua pihak atau lebih dalam jangka waktu tertentu untuk meraih keuntungan bersama (Maharatih et al., 2017). Sistem kemitraan yang saat ini sedang berkembang di Indonesia adalah sistem kemitraan Inti plasma. Kemitraan Inti plasma merupakan kerjasama antara perusahaan inti yang menyediakan sapronak (sarana produksi ternak) sedangkan peternak sebagai plasma yang menyediakan kandang dan peralatan untuk produksi. Dalam hal tersebut, plasma memiliki kewajiban menjual hasil panen kepada inti (Srimindarto, 2015). 
Di Bali terdapat dua perusahaan besar yang menyediakan pelayanan kemitraan Inti plasma dengan sistem yang berbeda yang diberi nama sistem A dan sistem B. Penelitian ini sangat penting dilakukan untuk membandingkan kedua sistem kemitraan tersebut.

\section{MATERI DAN METODE}

\section{Waktu dan Tempat Penelitian}

Penelitian dilaksanakan di Desa Candikusuma, Kecamatan Melaya, Kabupaten Jembrana, Bali selama 2 bulan yaitu bulan September sampai November 2019.

\section{Jenis dan Sumber Data}

Jenis data yang digunakan dalam penelitian adalah data kuantitatif dan data kualitatif. Data kuantitatif antara lain: jumlah ayam yang dipelihara, berat DOC, jumlah pemberian pakan, vaksin, obat-obatan, jumlah afkir serta mortalitas. Data kualitatif antara lain: jenis pakan, penanganan penyakit, manajemen pemeliharaan, sistem perjanjian kontrak dengan sistem A dan sistem B. Sumber data yang digunakan adalah data primer dan data sekunder, data primer berupa data selama satu periode pemeliharaan terakhir yang diperoleh langsung melalui wawancara dan observasi. Data sekunder antara lain: Data pemeliharaan milik peternak selama 6 periode terakhir dan data dari sistem A dan sistem B yang meliputi data standar performa produksi, harga kontrak dan sistem pembagian hasil.

\section{Variabel Penelitian}

Variabel yang diamati adalah Pola Kemitraan pada sistem kemitraan A dan sistem kemitraan B serta performa produksi ayam broiler yang meliputi: a) Umur panen, b) Pertambahan bobot badan, c) Konsumsi pakan, d) Deplesi, e) Feed convertion ratio (FCR), dan Indeks performa (IP).

\section{Teknik Pengumpulan Data}

Pengumpulan data dilakukan dengan cara observasi, wawancara, dan dokumentasi. Peneliti telah melakukan observasi selama satu periode produksi, mewawancarai pemilik peternakan dan dokumentasi dilakukan dengan mencatat data selama 7 periode produksi terakhir. 


\section{Analisis Data}

Data yang diperoleh dari penelitian ini dianalisis secara deskriptif, pada aspek pola kemitraan dari sitem A dan B serta performa produksi ayam broiler.

\section{Analisis performa produksi}

Analisis performa produksi ayam broiler dalam dihitung dengan rumus berikut:

1. Bobot Badan dihitung dengan rumus (Rose,1997)

$$
\text { Bobot Badan }=\frac{\text { Bobot Timbang }(\mathrm{kg})}{\text { Jumlah Ayam }(\mathrm{kg})}
$$

2. Pertambahan bobot badan dihitung dengan mencari selisih bobot panen dengan bobot awal (Tillman et al.,1986)

$\mathrm{PBB}=$ Bobot panen (kg/ekor) - Bobot badan awal (kg/ekor)

3. Nilai FCR dihitung dengan rumus (Edjeng dan Kartasudjana, 2006)

$$
\mathrm{FCR}=\frac{\text { Jumlah Konsumsi Pakan }(\mathrm{kg})}{\text { Pertambahan Bobot Badan Ayam }(\mathrm{kg})}
$$

4. Rata-rata umur panen dihitung dengan rumus (Ahmad, S. 2006)

$$
\text { Rata-rata umur panen }=\frac{\text { Jumlah ayam panen }(\text { ekor }) \times \text { Umur panen }(\text { han })}{\text { Total ayam panen }(\text { ekor })}
$$

5. Nilai Indeks Performa dihitung dengan rumus (Fadillah et al., 2007)

$$
\mathrm{IP}=\frac{\text { Persentase ayam hidup } \times \text { Bobot rata }(\mathrm{kg})}{\text { Ratarata umur panen (hari) } \times \text { konversi pakan }} \times 100
$$

6. Tingkat deplesi dihitung dengan rumus (Umam et al., 2014)

$$
\text { Deplesi }=\frac{\text { Jumlah ayarn mati (ekor) }+ \text { Culling (ekor) }}{\text { Populasi awal(ekor) }} \times 100 \%
$$

\section{HASIL DAN PEMBAHASAN}

\section{Perbandingan Sistem Kemitraan}

Hasil penelitian ini menunjukkan perbandingan antara sistem A dan sistem B disajikan pada Tabel 1. Kedua sistem tersebut sama-sama menerapkan kemitraan inti plasma dimana perusahaan bertindak sebagai inti dan peternak sebagai plasma. Sarana produksi peternakan 
seperti DOC, pakan dan obat-obatan disediakan oleh perusahaan inti, sedangkan peternak plasma menyediakan kandang, peralatan kandang, tenaga kerja, listrik, air dan litter. DOC yang diterima oleh peternak telah mendapatkan vaksin terlebih dahulu dari perusahaan inti. Dalam memenuhi target performa produksi masing-masing perusahaan menyediakan tenaga ahli yaitu technical service yang selalu memberikan pelayanan dan mengontrol manajemen dalam pemeliharaan. Pada pasca panen kedua perusahaan inti juga mengupayakan pemasaran hasil peternakan plasma, ayam hidup dibeli oleh perusahaan inti berdasarkan kontrak harga yang telah disepakati. Sistem pebagian hasil dilakukan dengan mengurangi hasil penjualan ayam dengan biaya sapronak yang diberikan oleh perusahaan inti. Sistem pembagian bonus yang diterapkan oleh kedua perusahaan berbeda yaitu pada Sistem A memberikan bonus berdasarkan FCR, Deplesi dan IP sedangkan pada sistem B memberikan bonus berdasarkan FCR dan harga pasar.

\section{Tabel 1. Perbandingan pola kemitraan sistem A dan sistem B.}

\begin{tabular}{|c|c|c|c|}
\hline No. & Indikator & Sistem A & Sistem B \\
\hline 1. & Pola Kerjasama & Inti plasma & Inti plasma \\
\hline 2. & $\begin{array}{l}\text { Sapronak (DOC, pakan dan } \\
\text { obat-obatan) }\end{array}$ & $\begin{array}{l}\text { Disediakan oleh } \\
\text { perusahaan }\end{array}$ & Disediakan oleh perusahaan \\
\hline 3. & Kandang dan peralatan & Disediakan oleh peternak & Disediakan oleh peternak \\
\hline 4. & $\begin{array}{l}\text { Kontrol pemeliharaan oleh } \\
\text { perusahaan }\end{array}$ & $\begin{array}{l}\text { Menyediakan technical } \\
\text { service }\end{array}$ & Menyediakan technical service \\
\hline 5. & Vaksinasi & $\begin{array}{l}\text { Telah memperoleh vaksin } \\
\text { lengkap dari perusahaan }\end{array}$ & $\begin{array}{l}\text { Telah memperoleh vaksin lengkap } \\
\text { dari perusahaan }\end{array}$ \\
\hline 6. & Pembagian hasil pemeliharaan & $\begin{array}{l}\text { Hasil pemeliharaan } \\
\text { peternak dikurangi dengan } \\
\text { biaya sapronak }\end{array}$ & $\begin{array}{l}\text { Hasil pemeliharaan peternak } \\
\text { dikurangi dengan biaya sapronak }\end{array}$ \\
\hline 7. & Sistem pemberian bonus & $\begin{array}{l}\text { Bonus FCR, IP dan } \\
\text { Deplesi }\end{array}$ & Bonus FCR dan bonus harga pasar. \\
\hline
\end{tabular}

Keterangan: FCR = Feed Conversion Ratio, IP = Indeks Performa

\section{Sistem Pembagian Bonus}

Sistem A akan memberikan bonus FCR jika peternak dapat menghasilkan FCR yang lebih rendah atau mendekati FCR standar. Perhitungan yang digunakan adalah FCR pemeliharaan dikurangi dengan FCR standar, hasil yang diperoleh disajikan dalam Tabel 2. 
Tabel 2. Perhitungan bonus sistem A

\begin{tabular}{|c|c|c|c|c|}
\hline No & Jenis Bonus & Performa & $\begin{array}{l}\text { Besaran Bonus } \\
\text { (Rp/kg panen) }\end{array}$ & Keterangan \\
\hline 1 & Bonus FCR & $\begin{array}{l}\leq 0,050 \\
0,051-0,100 \\
0,101-0,200\end{array}$ & $\begin{array}{l}200 \\
120 \\
100\end{array}$ & $\begin{array}{l}\text { Dihitung berdasarkan selisih } \\
\text { pemeliharaan dengan Standar FCR }\end{array}$ \\
\hline 2 & Bonus Deplesi & $<3 \%$ & 100 & Persentase Deplesi dibawah 3\% \\
\hline 3 & Bonus IP & $\begin{array}{l}\geq 85 \% \\
\geq 90 \% \\
\geq 100 \%\end{array}$ & $\begin{array}{l}100 \\
200 \\
300\end{array}$ & $\begin{array}{l}\text { Dihitung bedasarkan persentase capaian } \\
\text { IP dari Standar IP }\end{array}$ \\
\hline
\end{tabular}

Keterangan: FCR = Feed Conversion Ratio, IP = Indeks Performa

Bonus deplesi diberikan jika tingkat deplesi yang dihasilkan $<3 \%$ dengan bonus Rp.100/kg panen (Tabel 2). Perhitungan bonus IP diperoleh dengan cara menghitung IP pemeliharaan dibagi dengan IP standar dikali $100 \%$ yang disajikan pada Tabel 2. Jika peternak ingin memperoleh ketiga bonus yang ditawarkan oleh sistem A, maka pemeliharaan perlu ditingkatkan guna memperoleh performa produksi yang baik, karena syarat untuk memperoleh ketiga bonus tersebut adalah FCR yang rendah, tingkat deplesi yang rendah dan Indeks performa yang baik.

Sistem B memberikan bonus FCR dan harga pasar. Bonus FCR diberikan oleh sistem B jika peternak dapat menghasilkan FCR yang lebih rendah dari FCR standar. Perhitungan yang digunakan adalah FCR standar dikurangi dengan FCR pemeliharaan, hasil yang diperoleh tersaji dalam Tabel 3.

Tabel 3. Perhitungan bonus sistem B

\begin{tabular}{|c|c|c|c|c|}
\hline No & Jenis Bonus & Performa & $\begin{array}{c}\text { Besaran Bonus } \\
(\mathrm{Rp} / \mathrm{kg} \text { panen, \%) }\end{array}$ & Keterangan \\
\hline 1 & Bonus FCR & $\begin{array}{l}\geq 0,010 \\
\geq 0,026 \\
\geq 0,051 \\
\geq 0,076 \\
\geq 0,140\end{array}$ & $\begin{array}{l}150 \\
165 \\
170 \\
180 \\
200\end{array}$ & $\begin{array}{l}\text { Dihitung berdasarkan selisih standar FCR } \\
\text { dengan FCR pemeliharaan }\end{array}$ \\
\hline 2 & Bonus Pasar & $\begin{array}{c}\geq 0,01 \\
\geq 0,061 \\
\geq 0,081 \\
\geq 0,101 \\
\geq 0,121 \\
\geq 0,141\end{array}$ & $\begin{array}{c}15 \% \\
17,5 \% \\
20 \% \\
22,2 \% \\
25 \% \\
30 \%\end{array}$ & $\begin{array}{l}\text { Dihitung bedasarkan persentase selisih harga } \\
\text { pasar dengan harga kontrak. }\end{array}$ \\
\hline
\end{tabular}

Keterangan: FCR $=$ Feed Conversion Ratio

Bonus harga pasar diperoleh jika terdapat selisih harga pasar dengan harga kontrak dengan catatan FCR pemeliharaan lebih rendah dari FCR standar. Perhitungan yang digunakan adalah FCR standar dikurangi dengan FCR pemeliharaan, hasil yang diperoleh 
tersaji pada Tabel 3. Untuk memperoleh bonus pada sistem B sangat berpengaruh terhadap harga ayam hidup di pasaran, sehingga walaupun performa produksi yang dihasilkan oleh peternak baik harus didukung pula dengan harga pasar yang tinggi.

\section{Performa Produksi}

Bobot badan akhir ayam broiler merupakan penentu keberhasilan dari usaha peternakan karena hasil penjualan diukur berdasarkan bobot badan akhir yang dihasilkan. Rata-rata bobot badan ayam dalam tujuh periode pemeliharaan disajikan pada Tabel 4, ratarata bobot badan ayam mencapai berat $1,317 \mathrm{~kg} / \mathrm{ekor}$ dengan umur panen 29 hari, bobot badan tersebut lebih rendah dibandingkan dengan kedua standar perusahaan yaitu sistem A $1,549 \mathrm{~kg} / \mathrm{ekor}$ dan sistem B 1,646 kg/ekor. Rendahnya bobot badan akhir tersebut disebabkan oleh pertambahan bobot badan rata-rata yang rendah mencapai 1,278 kg/ekor. Hal tersebut diakibatkan oleh rendahnya konsumsi ransum yaitu 1,920 kg/ekor, sedangkan standar konsumsi ransum sistem A dan sistem B sebesar 2,203 kg/ekor dan 2,402 kg/ekor. Faktor yang menjadi kemungkinan penyebab konsumsi ransum rendah adalah suhu di dalam kandang yang melebihi standar yang diakibat oleh musim kemarau yang berkepanjangan. Dalam keadaan tersebut celldeck dan blower bekerja secara maksimal namun suhu di dalam kandang masih tinggi. Hasil pengamatan pada siang hari menunjukkan ayam panting yang disebabkan oleh pengaturan suhu yang tidak tercapai di dalam kandang, akibatnya konsumsi ransum akan turun dan berpengaruh terhadap pertambahan bobot badan. Hal ini diperkuat oleh Prawira et al., (2017) yang menyatakan bahwa tingginya suhu di dalam kandang dapat menyebabkan ayam broiler mengalami cekaman panas dan berpengaruh negatif terhadap performa produksi ayam broiler. Faktor lain yang menjadi kemungkinan penyebab rendahnya konsumsi ransum dan pertambahan bobot badan ayam broiler adalah pelarangan penggunaan Antibiotik growth promotor (AGP). Hal tersebut telah diteliti oleh Hidayatulah (2018) dengan hasil penelitian yang menyatakan bahwa konsumsi dan pertambahan bobot badan ayam broiler lebih tinggi dengan penambahan antibiotik pada ransum. Pemberian antibiotik diduga dapat menekan pertumbuhan mikroba pathogen dalam saluran pencernaan sehingga meningkatkan konsumsi ransum dan berpengaruh terhadap pertambahan bobot badan, hal tersebut diperkuat dengan pernyataan Kartini (2018), bahwa salah satu cara memodifikasi keseimbangann bakteri di dalam saluran pencernaan dengan pemberian antibiotik. 
Tabel 4. Bobot badan akhir, pertambahan bobot badan dan konsumsi ransum.

\begin{tabular}{ccccc}
\hline \multirow{2}{*}{ Periode } & $\begin{array}{c}\text { Umur panen } \\
\text { (hari) }\end{array}$ & BB akhir (kg/ekor) & $\begin{array}{c}\text { PBB } \\
\text { (kg/ekor) }\end{array}$ & Konsumsi Ransum (kg/ekor) \\
\cline { 5 - 5 } & 29 & 1,200 & 1,163 & \\
2 & 25 & 1,270 & 1,233 & 1,700 \\
3 & 28 & 1,270 & 1,233 & 1,750 \\
4 & 30 & 1,450 & 1,413 & 1,790 \\
5 & 28 & 1,190 & 1,153 & 2,200 \\
6 & 30 & 1,210 & 1,173 & 1,800 \\
7 & 34 & 1,630 & 1,581 & 2,700 \\
\hline Rata-rata & 29 & 1,317 & 1,278 & 1,920 \\
\hline Standar & & & & \\
Sistem A & 29 & 1,549 & 1,512 & 2,203 \\
\hline Standar & & & & \\
Sistem B & 29 & 1,646 & 1,604 & 2,402 \\
\hline
\end{tabular}

Keterangan: $\mathrm{BB}=$ Bobot Badan, $\mathrm{PBB}=$ Pertambahan Bobot Badan

Feed convertion ratio merupakan salah satu indikator yang penting untuk mengetahui tingkat efisiensi dalam penggunaan pakan. Rata-rata FCR pada tujuh periode pemeliharaan disajikan pada Tabel 5. FCR tersebut sebesar 1,488, yang artinya untuk mendapatkan bobot 1 $\mathrm{kg}$ ayam broiler diperlukan 1,488 kg pakan. Jika dibandingkan dengan standar FCR sistem A 1,420 dan sistem B 1,460 hasil pemeliharaan menunjukkan nilai FCR yang lebih tinggi, artinya kurang efisien dalam memanfaatkan pakan. Faktor-faktor yang mempengaruhi FCR selama pemeliharaan diantaranya yaitu suhu, dan pelarangan AGP (Antibiotik growth promotor) pada ransum. Didukung dengan pernyataan Lacy dan Vest (2000) bahwa faktor yang mempengaruhi FCR adalah genetik, ventilasi, sanitasi, kualitas ransum, jenis ransum, penggunaan zat aditif, kualitas air, penyakit, pengobatan, faktor penerangan, dan pemberian ransum.

Tingkat deplesi rata-rata pada tujuh periode pemeliharaan disajikan pada Tabel 5. Hasil deplesi pemeliharaan sebesar 2,276\% lebih rendah dibandingkan dengan standar deplesi sistem A 2,800\% dan sistem B 3,100\%. Hal tersebut dipengaruhi oleh rendahnya tingkat kematian dan culling. Tingkat kematian yang rendah disebabkan karena sanitasi kandang yang baik yaitu dilakukan penyemprotan litter dengan cairan desinfektan dan membalik litter secara rutin. Penyemprotan desinfektan bertujuan untuk membunuh bibit penyakit dan menurunkan kadar amonia yang terdapat pada litter, selain itu membalik litter bertujuan untuk menjaga litter agar tetap kering sehingga kadar amonia akan menurun. Kadar amonia yang rendah di dalam kandang berpengaruh terhadap kesehatan ayam. Pemberian vitamin secara berkala menjadi salah satu faktor pendukung yang menyebabkan rendahnya tingkat deplesi. Vitamin dapat meningkatkan daya tahan tubuh ayam terhadap serangan penyakit. Hal tersebut sejalan dengan pendapat Kusnadi (2006) yang menyatakan bahwa faktor-faktor yang 
mempengaruhi tingkat deplesi diantaranya adalah sanitasi kandang dan peralatan, kebersihan lingkungan serta penyakit.

Indeks performa merupakan salah satu kriteria yang digunakan untuk mengetahui keberhasilan pemeliharaan ayam broiler. Semakin besar nilai IP yang diperoleh, semakin baik prestasi ayam dan semakin efisien penggunaan pakan (Fadilah et al., 2007). Rata-rata IP yang diperoleh pada penelitian ini disajikan pada tabel 5 sebesar 297,490, hasil tersebut lebih rendah dibandingkan dengan standar IP sistem A 365,000 dan sistem B 376,000. Menurut Santoso dan Sudaryani (2009), kriteria IP < 300 termasuk dalam kriteria kurang. Hal tersebut dikarenakan oleh bobot akhir ayam broiler yang masih rendah serta FCR yang diperoleh masih tinggi.

Tabel 5. Tingkat FCR, deplesi dan indeks performa pemeliharaan ayam broiler

\begin{tabular}{ccccc}
\hline Periode & $\begin{array}{c}\text { Umur panen } \\
\text { (hari) }\end{array}$ & FCR & Deplesi (\%) & IP \\
\hline 1 & 29 & 1,482 & 2,500 & 271,431 \\
2 & 25 & 1,398 & 1,230 & 359,000 \\
3 & 28 & 1,444 & 2,460 & 306,000 \\
4 & 30 & 1,550 & 2,380 & 304,000 \\
5 & 28 & 1,537 & 2,080 & 271,000 \\
6 & 30 & 1,445 & 2,500 & 272,000 \\
7 & 34 & 1,560 & 2,780 & 299,000 \\
\hline Rata-rata & 29 & 1,488 & 2,276 & 365,000 \\
\hline Standar & 29 & 1,420 & 2,800 & 376,000 \\
Sistem A & 29 & 1,460 & 3,100 & \\
\hline Standar & 29 & &
\end{tabular}

Keterangan: FCR $=$ Feed Conversion Ratio, $\mathrm{IP}=$ Indeks Performa

\section{SIMPULAN DAN SARAN}

\section{Simpulan}

1. Sistem A dan sistem B sama-sama menerapkan pola kemitraan inti plasma dimana perusahaan bertindak sebagai inti dan peternak sebagai plasma. Perusahaan inti bertugas menyediakan sapronak seperti DOC, pakan, dan obat-obatan serta menyediakan pembinaan teknis, sedangkan sarana produksi seperti kandang, peralatan kandang, tenaga kerja, listrik, air dan litter disediakan oleh peternak. Sapronak yang diberikan oleh inti akan dibayar oleh peternak melalui pemotongan hasil panen. Perbedaan kedua sistem kemitraan tersebut terletak pada sistem pembagian bonus. 
2. Rata-rata performa produksi yang dihasilkan dari 7 periode pemeliharaan masih di bawah standar sistem A dan sistem B, namun tingkat deplesi sudah cukup baik di atas standar kedua sistem.

\section{Saran}

1. Sebagai peternak maupun calon peternak agar lebih selektif dalam memilih perusahaan inti karena memiliki keunggulan dan kelemahannya masing-masing

2. Penerapan manajemen pemeliharaan yang baik harus selalu diperhatikan dalam pemeliharaan ayam broiler agar performa produksi yang ditetapkan masing-masing perusahaan dapat tercapai maupun terlampaui.

\section{UCAPAN TERIMA KASIH}

Penulis mengucapkan terima kasih kepada Prof. Dr.dr. A. A. Raka Sudewi, Sp.S (K) selaku Rektor Universitas Udayana dan Dr. Ir. I Nyoman Tirta Ariana, M.S selaku Dekan Fakultas Peternakan Universitas Udayana yang telah memberikan kesempatan dan fasilitas kepada penulis untuk mengikuti dan menyelesaikan pendidikan di Program Studi Sarjana Peternakan, Fakultas Peternakan, Universitas Udayana.

\section{DAFTAR PUSTAKA}

Ahmad, S. 2006. Strategi Kemitraan dalam Saluran Distribusi untuk Meningkatkan Kinerja Bisnis. Program Studi Magister Manajemen Program Pasca Sarjana Universitas Diponegoro, Semarang.

Badan Pusat Statistik Indonesia. Rata-rata Konsumsi daging ayam ras per kapita 2007-2018. 2019. https://www.bps.go.id/statictable/2014/09/08/950/rata-rata-konsumsi-kapitaseminggu-beberapa-macam-bahan-makanan-penting-2007-2018.html (Diakses 31 Agustus 2019)

Badan Pusat Statistik Indonesia. Laju Pertumbuhan Penduduk Menurut Provinsi 2015-2019. 2019. https://www.bps.go.id/statictable/2009/02/20/1268/laju-pertumbuhan-pendudukmenurut-provinsi.html (Diakses 31 Agustus 2019)

Edjeng S. dan Kartasudjana, R. 2006. Manajemen Ternak Unggas. Penebar Swadaya, Jakarta.

Fadilah, R., A. Polana, S. Alamdan E. Purwanto. 2007. Sukses Beternak Ayam Broiler. Agromedia Pustaka, Jakarta.

Hidayatullah, S. 2018. Performa broiler yang diberikan antibiotic dan probiotik. Fakultas Sains dan Teknologi Universitas Islam Negeri Alauddin. Makasar

Kartini. 2008. Pengaruh pemberian antibiotic terhadap konsumsi pakan, pertambahan berat badan dan konversi pakan. Fakultas Peternakan Universitas Hasanuddin. Makasar

Kusnadi, E. 2006. Suplementasi vitamin c sebagai penangkal cekaman panas pada ayam broiler. JITV vol 11 no 4. Fakultas Peternakan Universitas Andalas. Padang 
Lacy, M. and L. R. Vest. 2000. Improving Feed Convertion in Broiler: A Guide for Growers. Springer Science and Business Media Inc, New York.

Maharatih, N. M. D., I W. Sukanata. I P, A. Astawa. 2017. Analisis performance usaha ternak ayam broiler pada model kemitraan dengan sistem open house (Studi kasus di Desa Baluk Kkecamatan Negara). Peternakan Tropika Vol. 5 N0. 2 Th 2017: 407-416. Bali. https://ojs.unud.ac.id/index.php/tropika/article/view/33781/21357

Prawira, I G. I. K., I G. Mahardika., I W. Sukanata. 2017. Analisis pendapatan peternak ayam broiler dengan sistem pemeliharaan closed house pada pola kemitraan (Studi kasus di peternakan Plasma Sri Budi Ratini, Desa Candikusuma, Kecamatan Melaya, Kabupaten Jembrana). Peternakan Tropika Vol. 5 N0. 2 Th 2017: 238-250. Bali. https://ojs.unud.ac.id/index.php/tropika/article/view/33598/20326

Primaditya, F. M., Hidanah, S., dan Soeharsono. 2015. Analisis Pendapatan dan Produktivitas Ayam Petelur Sistem "Closed house" dengan Penggunaan Mesin Pakan Otomatis dan Manual di Kuwik Farm, Kecamatan Badas, Pare. Agroveteriner: Vol.3, No.2 Juni 2015.

Rose, S. P. 1997. Principle of Polutry Science. CAB International, New York

Santoso, H., dan Sudaryani, T. 2009. Pembesaran Ayam Pedaging di Kandang Panggung Terbuka. Jakarta: Penebar Swadaya. Hal: 5; 10; 18; 24-32; 40; 86-88.

Srimindarto E. 2015. Pola Hubungan Kemitraan Inti Plasma Pada Usaha Ternak Ayam Broiler (Studi Kasus Pada PT.Bina Karya Sejati di Kecamatan Jatirogo Kabupaten Tuban). Skripsi. Fakultas Ilmu Sosial Negri Semarang.

Tillman, A.D., H. Hartadi., S. Reksohadiprodjo., S. Prawirokusumo dan S. Lebdosoekojo. 1986. Ilmu Makanan Ternak Dasar. Fak Peternakan. Gajah Mada University Press, Yogyakarta

Wulansari, P. K. P., I W. Sukanata, I M. Suasta. 2018. Analisis Pendapatan Peternakan Ayam Broiler dengan Sistem Kandang Tertutup (Closed House) pada Pola Mandiri (Studi Kasus pada CV. Sari Mulya di Desa Tunjuk, Tabanan). Peternakan Tropika Vol. 6 No. 3 Th 2018: 893-903. Bali. https://ojs.unud.ac.id/index.php/tropika/article/view/43603 